\title{
POPULASI DAN SERANGAN Cnaphalocrosis medinalis (LEPIDOPTERA; PYRALIDAE) PADA TANAMAN PADI SAWAH DI KABUPATEN MINAHASA TENGGARA
}

\author{
POPULATION AND INSECT PESTS ATTACK OF Cnaphalocrosis medinalis \\ (LEPIDOPETRA ; PYRALIDAE) ON RICE IN SOUTHEAST MINAHASA
}

\author{
Moulwy F. Dien dan Daisy S. Kandowangko*) \\ *)Jurusan Hama dan Penyakit Tumbuhan, Fakultas Pertanian \\ Universitas Sam Ratulangi \\ e-mail: roydien@yahoo.com
}

\begin{abstract}
The experiment was conducted using a survey method at 4 locations/district in the Southeast Minahasa Regency is Belang,Tombatu, North Tombatu, and East Tombatu. Each location/districts determined three paddy fields (repeats) as a place of observation and sampling. The study lasted for 10 months ie from January to October 2015. Sampling is done diagonally to the respective fields. So one rice field consists of 5 sub-plot as a point of sampling Samples are larvae present in the leaf roll. Implementation of the sampling carried out on rice plants vegetative phase once a week for 6 weeks. The results showed that the average population of $C$. medinalis (per-10 clumps) on paddy rice cultivation in Southeast Minahasa Regency highest found in the location of the North Tombatu 10.99, then Eastern Tombatu 10.44, Belang 10.43 and lows in the Tombatu 0.94. Observations of percentage of pests $C$. medinalis highest in Southeast Minahasa Regency found in the sample locations in the North Tombatu which reached $33.95 \%$, Belang $32.51 \%$, Eastern Tombatu $31.86 \%$, and the lowest in the Tombatu $4.08 \%$.
\end{abstract}

Keywords : rice, Cnaphalocrosis medinalis

\section{ABSTRAK}

Penelitian dilaksanakan pada pertanaman padi sawah di Kabupaten Minahasa Tenggara. Waktu penelitian selama 10 bulan yakni sejak bulan Januari sampai dengan Oktober 2015. Penelitian menggunakan metode survei pada 4 lokasi di Kabupaten Minahasa Tenggara, yakni di Kecamatan Belang, Kecamatan Tombatu, Kecamatan Tombatu Utara, Kecamatan Tombatu Timur. Masing-masing lokasi/kecamatan ditentukan tiga petak sawah (ulangan). Pengambilan sampel dilakukan secara diagonal pada masing-masing petak sawah. Jadi 1 petak sawah terdiri dari 5 sub petak sebagai tempat pengambilan sampel sampel adalah larva yang terdapat di dalam gulungan daun. Rata-rata populasi Cnaphalocrosis medinalis (per-10 rumpun) pada pertanaman padi sawah di Kabupaten Minahasa Tenggara tertinggi ditemukan pada lokasi Kecamatan Tombatu Utara yakni mencapai 10,99 ekor, kemudian Kecamatan Tombatu Timur 10,44 ekor, Kecamatan Belang 10,43 ekor dan Kecamatan terendah di Kecamatan Tombatu 0,94 ekor. Serangan C. medinalis tertinggi dijumpai pada tanaman berumur 6 minggu setelah tanam (mst) yakni mencapai 20,66\%, kemudian tanaman berumur 5 mst mencapai $13,55 \%$, tanaman berumur 4 mst mencapai $10,88 \%$, tanaman berumur 3 mst mencapai $7,55 \%$, tanaman berumur 2 mst mencapai 0,18 \% ; sedangkan pada tanaman berumur 1 tidak dijumpai serangan. Persentase serangan hama Cnaphalocrosis medinalisdi Kabupaten Minahasa Tenggara tertinggi dijumpai pada lokasi sampel di Kecamatan Tobatu Utara yakni mencapai 33,95\%, kemudian berturut-turut Kecamatan Belang 32,51 \%, Kecamatan Tombatu Timur 31,86 \% dan terendah di Kecamatan Tombatu 4,08 \%,.

Kata kunci : padi, Cnaphalocrosis medinalis

Eugenia Volume 23 No. 1 Pebruari 2017 


\section{PENDAHULUAN}

Upaya peningkatan hasil pertanian terus dilakukan oleh Pemerintah Kabupaten Minahasa Tenggara (Mitra) dengan mengembangkan lahan produktif yakni berupa sawah dan ladang. Berdasarkan data yang dimiliki Distanak Mitra, jumlah lahan produktif di daerah tersebut mencapai 2.978 Hektar ( $\mathrm{Ha})$. Namun meski demikian, lahan produktif tersebut belum memberikan hasil seperti yang diharapkan (Anonim, 2014).

Teknik bercocok tanam yang baik sangat diperlukan untuk mendapatkan hasil yang sesuai dengan harapan. Hal ini harus dimulai dari awal, yaitu sejak dilakukan pesemaian sampai tanaman tersebut bisa dipanen. Dalam proses pertumbuhan tanaman hingga berbuah harus dipelihara yang baik, terutama harus diusahakan agar tanaman terhindar dari serangan hama dan penyakit yang sering kali menurunkan produksi (Anonim, 2007a; Anonim, 2008).

Dalam proses intensifikasi sekarang ini berbagai kendala sosial ekonomi dan teknis bermunculan. Masalah Organisme Pengganggu Tanaman (OPT) yang mengakibatkan penurunan produksi dan masalah ini belum dapat diatasi dengan memuaskan. Kehilangan hasil akibat OPT diperkirakan $40-55 \%$, bahkan dapat terancam gagal panen (Anonim, 2003; Baehaki, 2009).

Cnaphalocrosis medinalis merupakan salah satu hama penting pada tanaman padi (Kalshoven, 1981). Hasil pengamatan ditemukan beberapa petak tanaman padi sawah khususnya di Kabupaten Minahasa Tenggara terserang hamaC. medinalis. Hal ini terlihat dari adanya gejala serangan berupa terlipatnya daun tanaman padi dan terdapat larva di dalamnya.

Salah satu kendala di dalam upaya peningkatan produksi padi adalah adanya gangguan serangga hama sebagai organisme penganggu tanaman. Cnaphalocrosis medinalis merupakan salah satu hama penting pada tanaman padi. Hama ini mulai menyerang sejak tanaman masih muda sampai tanaman yang telah berbuah Gangguan hama ini dapat menurunkan produksi padi dan pada serangan berat dapat menyebabkan gagal panen.
C. medinalis merupakan salah satu hama penting yang menyerang tanaman padi yang akibat serangannya akan berdampak pada terjadinya penurunan produksi padi. Mengetahui keadaan serangan dan populasi hama ini merupakan langkah awal di dalam upaya pengendaliannya sehingga dapat diketahui penyebaran dan penyebab tingginya populasi dan tingkat kerusakan pada tanaman padi.

Tujuan penelitian ini adalah: a) Mengetahui seberapa besar serangan hamaC. medinalis pada tanaman padi sawah di Kabupaten Minahasa Tenggara; b) Mengetahui populasi hama $C$. medinalis pada tanaman padi sawah di Kabupaten Minahasa Tenggara

Hasil penelitian ini diharapkan dapat diketahui serangan dan populasi hama C. medinalis pada pertanaman padi sawah yang merupakan informasi penting sebagai bahan pertimbangan di dalam penyusunan strategi pengendalian hama $C$. medinalis di masa yang akan datang. Dengan demikian petani dapat mengantisipasi populasi dan serangan $\mathrm{C}$. medinalis sehingga kerusakan tanaman dapat segera di cegah.

\section{METODE PENELITIAN}

Penelitian dilaksanakan pada pertanaman padi sawah di Kabupaten Minahasa Tenggara. Waktu penelitian selama 10 bulan yakni sejak bulan Januari sampai dengan Oktober 2015.

Penelitian menggunakan metode survei pada 4 lokasi di Kabupaten Minahasa Tenggara, yakni di Kecamatan Belang, Kecamatan Tombatu, Kecamatan Tombatu Utara, Kecamatan Tombatu Timur. Masing-masing lokasi/kecamatan ditentukan tiga petak sawah (ulangan).

Survei bertujuan untuk mengetahui dan menetapkan lokasi penelitian. Kriteria lokasi penelitian adalah terdapatnya pertanaman padi sawah berumur $<1$ minggu sekurang-kurangnya berjumlah tiga petak sawah. 


\section{Pengambilan Sampel}

Pengambilan sampel dilakukan secara diagonal pada masing-masing petak sawah. Jadi 1 petak sawah terdiri dari 5 sub petak sebagai tempat pengambilan sampel. Sampel adalah larva yang terdapat di dalam gulungan daun.

Sampel yang ditemukan dikoleksi di dalam alkohol $70 \%$, kemudian dibawa ke Laboratoriun Entomologi dan Hama Tumbuhan untuk diidentifikasi. Pengambilan sampel dilakukan pada tanaman fase vegetatif seminggu sekali selama enam minggu.

\section{Hal-hal yang diamati Populasi Larva}

Ditetapkan 10 rumpun secara acak pada masing-masing sub-petak yang akan diamati. Pengamatan pupulasi dilakukan dengan cara mengambil larva yang di temukan pada sub-petak kemudian dihitung jumlahnya. Untuk menghitung populasi larva $C$. medinalis digunakan rumus:

$$
\text { Rata-rata }=\frac{\text { Jumlah larva yang ditemukan }}{\text { Banyaknya pengamatan }}
$$

\section{Persentase Serangan}

Pada masing-masing sub-petak ditentukan 50 rumpun yang akan diamati. Jadi, jumlah rumpun yang diamati pada masing-masing petak sebanyak 250 rumpun. Persentase serangan dilakukan dengan mengamati sampel tanaman terserang yang menunjukkan gejala serangan hama putih palsu, kemudian menghitung jumlah rumpun yang terserang. Untuk menghitung persentase serangan hama putih palsu digunakan rumus sebagai berikut:

$$
S=\frac{n}{N}
$$

Keterangan:

$S=$ persentase tanaman terserang

$\mathrm{n}=$ jumlah rumpun terserang

$\mathrm{N}=$ jumlah rumpun yang diamati

\section{Analisis Data}

Data serangan C. medinalis yang diperoleh dianalisis dengan menggunakan analisis One Way Anova dengan SPSS Ver. 21.

\section{HASIL DAN PEMBAHASAN}

\section{Populasi Larva}

Pengamatan populasi hama menunjukkan bahwa rata-rata populasi Cnaphalocrosis medinalis (per-10 rumpun) pada pertanaman padi sawah di Kabupaten Minahasa Tenggara tertinggi ditemukan pada lokasi Kecamatan Tombatu Utara yakni mencapai 10,99 ekor, kemudian Kecamatan Tombatu Timur 10,44 ekor, Kecamatan Belang 10,43 ekor dan Kecamatan terendah di Kecamatan Tombatu 0,94 ekor, selengkapnya dapat dilihat pada Tabel 1.

Berdasarkan tabel 1 , bahwa serangan $C$. medinalis tertinggi dijumpai pada tanaman berumur 6 minggu setelah tanam (mst) yakni mencapai $20,66 \%$, kemudian tanaman berumur 5 mst mencapai $13,55 \%$, tanaman berumur 4 mst mencapai $10,88 \%$, tanaman berumur 3 mst mencapai $7,55 \%$, tanaman berumur 2 mst mencapai 0,18\%; sedangkan pada tanaman berumur 1 tidak dijumpai serangan.

Tabel 1, menunjukkan kecenderungan bahwa semakin tinggi umur tanaman semakin tinggi serangan hama $C$. medinalis. Pada tanaman berumur 1 minggu setelah tanam tidak ditemukan serangan. Hal ini diduga karena jumlah daun pada tanaman berumur 1 minggu masih relatif sedikit menyebabkan intensitas cahaya disekitar tanaman menjadi tinggi. Tingginya intensitas cahaya matahari dapat menyebabkan terjadinya peningkatan suhu sehingga diduga merupakan salah satu penyebab rendahnya populasi hama pada tanaman yang berumur 1 minggu setelah tanam.

Setiap spesies serangga mempunyai jangkauan suhu masing-masing dimana ia dapat hidup, dan pada umumnya jangkauan suhu yang efektif adalah suhu minimum. Serangga memiliki kisaran suhu tertentu untuk kehidupannya. Diluar kisaran suhu tersebut serangga dapat mengalami kematian. Efek ini terlihat pada proses fisiologis serangga, dimana pada suhu tertentu aktivitas serangga tinggi dan akan berkurang (menurun) pada suhu yang 
lebih rendah. Pada umumnya kisaran suhu yang efektif adalah suhu minimum $15^{\circ} \mathrm{C}$, suhu optimum $25^{\circ} \mathrm{C}$ dan suhu maksimum $45^{\circ} \mathrm{C}$. Pengaruh suhu jelas terlihat pada proses fisiologis serangga. Di luar kisaran suhu tersebut serangga akan mati kedinginan atau kepanasan. Fakta ini memperlihatkan bahwa semakin tinggi suhu akan semakin pendek umur serangga.

Suhu udara memegang peranan penting karena mempengaruhi kecepatan proses metabolisme dan kehidupan serangga dalam berbagai segi antara lain aktivitas serangga, penyebaran, mortalitas, dan perkembangannya. Lamanya perkembangan hidup serangga tergantung pada keadaan suhu lingkungan, sebab suhu yang rendah umumnya memperpanjang stadium telur serangga sebaliknya suhu yang tinggi dapat memperpendek stadium telur.

Tanaman padi yang terserang $C$. medinalis menunjukkan gejala berupa terdapatnya gulungan-gulungan pada daun tanaman padi. Larva hidup di dalam gulungan daun, dan memakan jarringan hijau daun, sehingga menyebabkan terbentuknya garis-garis putih transparan sepanjang $15-20 \mathrm{~cm}$. Jika gulungan daun dibuka biasanya ditemukan seekor larva di dalamnya.

\section{Persentase Serangan}

Pengamatan terhadap persentase serangan hama Cnaphalocrosis medinalis di Kabupaten Minahasa Tenggara tertinggi dijumpai pada lokasi sampel di Kecamatan Tobatu Utara yakni mencapai $33,95 \%$, kemudian berturut-turut Kecamatan Belang 32,51 \%, Kecamatan Tombatu Timur $31,86 \%$ dan terendah di Kecamatan Tombatu 4,08\%, selengkapnya dapat dilihat pada Tabel 2 .

Hasil analisis menunjukkan tidak adanya perbedaan pengaruh lokasi terhadap serangan $C$. medinalis. Rendahnya serangan C. medinalis diduga disebabkan karena kondisi lahan yang terawat. Lokasi lahan yang terawat menyebabkan tidak terdapatnya gulma yang dapat digunakan oleh hama sebagai inang alternatif. Hasil penelitian Warti (2006) melaporkan bahwa pada kondisi lahan yang bersih dimana tidak dijumpai gulma serangan C. medinalis cenderung rendah dibandingkan dengan lahan-lahan kotor dan tidak terawat. Dengan adanya sejumlah gulma maka dapat berkembang biak dengan baik. Gulma dapat berfungsi sebagai tempat yang baik untuk menghindari cahaya matahari ataupun bersembunyi dari predator.

Tabel 1. Rata-rata Populasi C. medinalis pada Tanaman Padi di Kabupaten Minahasa Tenggara

(Table 1. Average Larval Populations of C. medinalis to Rice in Southeast Minahasa Regency)

\begin{tabular}{lccccccc}
\hline \multirow{2}{*}{ Lokasi / Kecamatan } & \multicolumn{6}{c}{ Umur Tanaman (ming setelah tanam) per 10 rumpun } & $\begin{array}{c}\text { Rata-rata Populasi } \\
\text { (ekor) }\end{array}$ \\
\cline { 2 - 6 } & 1 & 2 & 3 & 4 & 5 & 6 & 10,43 \\
Belang & 0,00 & 0,20 & 1,60 & 11,60 & 19,40 & 29,80 & 0,94 \\
Tombatu & 0,00 & 0,00 & 0,33 & 1,40 & 1,06 & 2,86 & 10,99 \\
Tombatu Utara & 0,00 & 0,40 & 2,06 & 12,46 & 22,4 & 28,66 & 10,44 \\
Tombatu Timur & 0,00 & 0,13 & 1,20 & 8,46 & 18,53 & 34,33 & \\
\hline Rata-rata & 0 & 0,18 & 7,55 & 10,88 & 13,5 & 20,66 & \\
\hline
\end{tabular}

Tabel 2. Rata-rata persentase serangan C. medinalis pada tanaman padi di Kabupaten Minahasa Tenggara (Table 2. Average percentage of attacks C. medinalis to rice in Southeast Minahasa Regency)

\begin{tabular}{lccccccc}
\hline \multirow{2}{*}{ Lokasi / Kecamatan } & \multicolumn{9}{c}{ Umur Tanaman (minggu setelah tanam) } & \multicolumn{2}{c}{ Rata-rata } \\
\cline { 2 - 6 } & 1 & 2 & 3 & 4 & 5 & 6 & persentase \\
\hline Belang & 0,00 & 0,40 & 9,46 & 36,66 & 57,46 & 91.13 & 32,51 \\
Tombatu & 0,00 & 0,00 & 2,00 & 6,00 & 4,80 & 11,73 & 4,08 \\
Tombatu Utara & 0,00 & 0,26 & 9,73 & 35,46 & 69,33 & 88,93 & 33,95 \\
Tombatu Timur & 0,00 & 0,00 & 7,33 & 27,46 & 61,73 & 94,66 & 31,86 \\
\hline
\end{tabular}


Tabel 3. Hasil Analisis One Way Anova dengan SPSS Ver. 21 Serangan C. medinalis pada Tanaman Padi di Kabupaten Minahasa Tenggara

(Table 3. Results of Analysis of One Way Anova with SPSS Ver . 21 Attacks C. medinalis to Rice in Southeast Minahasa Regency)

Persentase

\section{Descriptives}

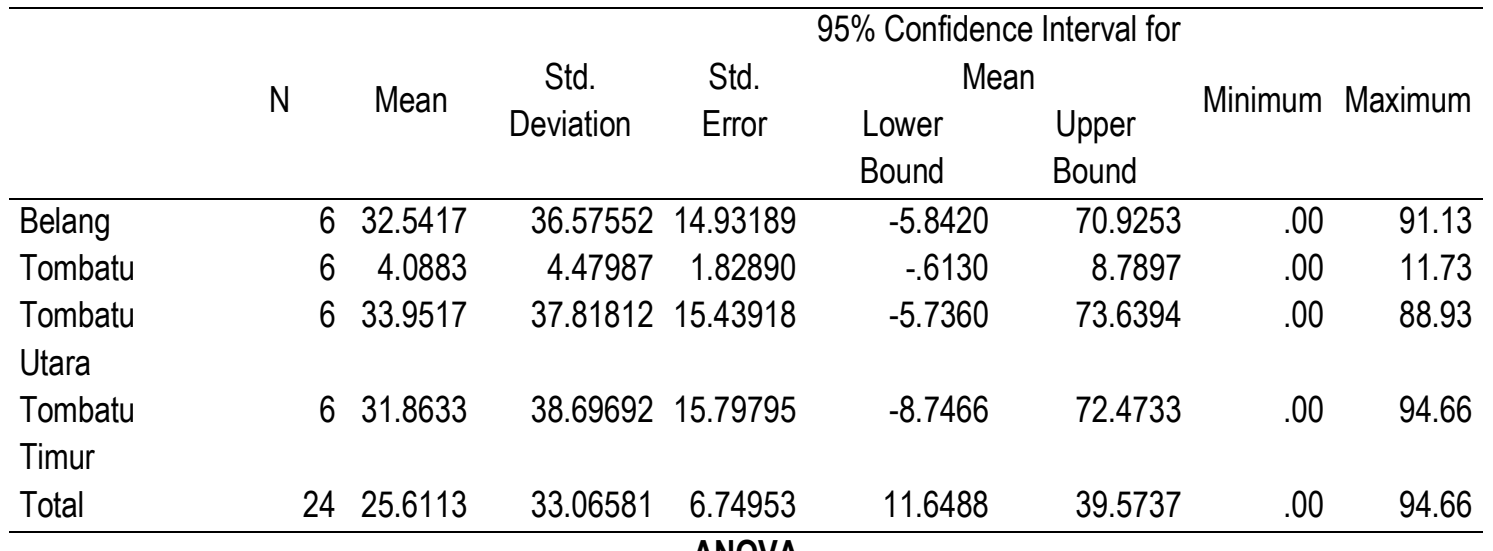

Persentase

\begin{tabular}{|c|c|c|c|c|c|}
\hline & Sum of Squares & $\mathrm{df}$ & Mean Square & $\mathrm{F}$ & Siq. \\
\hline Between Groups & 3719.506 & 3 & 1239.835 & 1.157 & .351 \\
\hline Within Groups & 21427.499 & 20 & 1071.375 & & \\
\hline Total & 25147.005 & 23 & & & \\
\hline
\end{tabular}

\section{KESIMPULAN DAN SARAN}

\section{Kesimpulan}

Populasi hama Cnaphalocrosis medinalis di Kabupaten Minahasa Tenggara tertinggi ditemukan pada yakni mencapai 10,99 ekor, lokasi Kecamatan Tombatu Utara kemudian Kecamatan Tombatu Timur 10,44 ekor, Kecamatan Belang 10,43 ekor dan di Kecamatan Tombatu 0,94 ekor.

Serangan C. medinalis tertinggi dijumpai pada tanaman berumur 6 minggu setelah tanam (mst) yakni mencapai $20,66 \%$, kemudian tanaman berumur 5 mst mencapai $13,55 \%$, tanaman berumur 4 mst mencapai $10,88 \%$, tanaman berumur 3 mst mencapai $7,55 \%$, tanaman berumur $2 \mathrm{mst}$ mencapai $0,18 \%$; sedangkan pada tanaman berumur 1 mst tidak dijumpai serangan.
Saran

Perlu penelitian lanjutan terutama untuk mengetahui populasi dan serangan hama-hama tanaman padi lainnya.

\section{UCAPAN TERIMA KASIH}

Disampaikan terima kasih kepada semua pihak yang telah membantu pelaksanaan penelitian ini. Tulisan ini merupakan hasil penelitian Research Unggulan Universitas Sam Ratulangi (RUU) Tahun 2015 yang dibiayai dari Daftar Isian Pelaksanaan Anggaran (DIPA) Nomor: SP DIPA042.04.2.400097/2015 Tanggal 15 April 2015. Satuan Kerja Universitas Sam Ratulangi. Kementerian Riset, Teknologi dan Pendidikan Tinggi. 


\section{DAFTAR PUSTAKA}

Amirullah, A. $2008 . \quad$ Budidaya Padi. http://amiere.multiply.com/ journal/item/27 B Budidaya padi.

Anonim. 2003. Pedoman Rekomendasi Pengendalian Hama Terpadu Pada Tanaman Padi. Direktorat Perlindungan Tanaman, Direktorat Jenderal Bina Produksi Tanaman Pangan. Dep. Pertanian. Jakarta. 2007a. Peningkatan Produksi Padi Menuju 2020. Pusat Penelitian dan Pengembangan Tanaman Pangan. http://www.puslittan. bogor.net /index.

2008. Teknologi Padi. Informasi Ringkas. http://www.knowledgebank.irri.org/ indonesia/PDF\%20files/penggerek_BW.pd f.
,2009. Hama Putih Palsu.Cnaphalocrocis medinalis Guenee.Pusat penelitian dan Pengembangan Tanaman Pangan. http://www.pustaka-deptan.go.id

2014. Pemkab Minahasa Tenggara Terus Optimalkan Lahan Produktif. http://indonesia-timur.co/2014/02/08/ pemkab-minahasa-tenggara-terusoptimalkan-lahan-produktif/

Arifin, S. 2012. Hama Putih Palsu Sebabkan Tanaman Padi Mati. http://theglobe journal.com/varia/-hama-putih-palsusebabkan-tanaman-padi-mati/index.

Baehaki, S. E. 2009. Strategi Pengen-dalian Hama Terpadu Tanaman Padi dalam Perspektif Praktek Pertanian yang Baik. (Good Agricultural practice). www.pus-takadeptan.go.id/publikasi/ip.pdf. 